\title{
6. Corporate responsibility and social sustainability: Is there any connection?
}

\section{Katherine Trebeck}

This chapter examines the relationship between corporate social responsibility and social sustainability on the premise that a vital ingredient in social sustainability is the capacity of communities to determine, or at least influence, those decisions that impact them. Communities should be able to influence decisions regarding any trade-offs that may affect them - for example, between economic development and environmental conservation or between meeting the needs of current generations and the capacity of future generations to meet their needs. Local communities ${ }^{1}$ in particular, need to determine what is to be sustained, how and at what expense - not only because their lives are impacted by these decisions, but also because local communities are crucial players in processes seeking to enhance sustainability. Corporate actions are clearly relevant in these trade-offs, but if, as seen here, the state proves itself a poor mediator between company behaviour and the desires of local communities, then local communities need to confront companies directly.

It is this interface that is the subject of this chapter-how responsive companies are to the demands of local communities and in what circumstances. It considers what drives miners to respond to the demands of certain communities in order to elucidate when and where communities, in all their complexity, can exert leverage over companies to make corporate behaviours correspond more with the desires of those affected by corporate actions. The case study of mining companies and their relations with Indigenous communities in Australia is used to evaluate whether the tool of 'civil regulation' might advance the sovereignty of local communities, so contributing to sustainability and enhancing democracy.

Four examples indicate that corporate responsiveness depends on individuals inside companies perceiving and utilising the 'business case' for socially responsible behaviour to pursue corporate change in the direction demanded by particular communities. This 'business case', however, depends on communities maintaining vigilance and sustaining a context that impels companies to respond to community demands. Implications for social sustainability arising from this will be set out in the conclusion. Before examining

\footnotetext{
${ }^{1}$ Local communities can be seen as linked by a shared space — thus 'communities of geography' —other communities might be linked by a mutual concern in an issue - ' communities of interest', or by common experience of being affected by a particular development or entity-hence, 'communities of fate' (see Held 2004, who describes the world as comprising 'overlapping communities of fate'; also Hirst 1994: 49).
} 
several 'vignettes' where civil regulation has been effective theories of corporate social responsibility, democracy and social sustainability, and civil regulation are outlined to frame discussion. Instances of civil regulation and corporate change are the Century mine negotiations and sit-in, Hamersley Iron's Marandoo dispute, Rio Tinto's adoption of corporate social responsibility, and the campaign to stop the Jabiluka uranium mine.

Analysis is informed by over 120 semi-structured interviews conducted from 2002 to 2005 with all levels of company personnel and many industry observers, regulators, bureaucrats, stock market participants, environmental and community activists and academics, as well as consideration of corporate publications and other quantitative sources to contextualise personal accounts. This supporting material included annual reports, corporate statements of a company's vision and operating principles, websites, brochures and other publications, survey questions and results, speeches, media releases, media reports and company statistics.

\section{Democracy and social sustainability}

Democratisation is advanced when political decision-making becomes more inclusive - when citizens become involved in those decisions that affect them (Whitehead 2002). ${ }^{2}$ The capacity of communities to determine, or at least influence, those decisions that impact them is a fundamental aspect of sustainability. Advocates of more participatory modes of democracy, however, often complain that contemporary configurations of parliamentary representation are inadequate (see, for example, Barber 1984; de Tocqueville 1945; Dryzek 2000b; Fox and Miller 1995; Hirst 1994; Odd Var Eriksen 2000; Pateman 1970; see also Rayner 1997 for a comprehensive account of the pit-falls of Australia's representative structure). Formal democratic political processes, invariably parliamentary representation, are accessible to some groups more than others, reinforcing social and economic disparities, and deepening political inequality (Young 2000; see also Dahl 1985; Klausen and Sweeting 2003). Globalisation and corporate power seem to be encroaching on the ability of representative government to uphold citizens' interests (see, for example, Bang and Bech Dyrbery 2000; Etzioni-Halevy 2003; Korten 2001; Miller 2003). Consequently, government action frequently does not reflect the wishes of particular communities.

With access and influence in formal parliamentary democracy often determined by possession of resources, Indigenous Australians are especially disenfranchised by the contours of representative democracy. A diversity of factors-historical, political, cultural and structural - can potentially explain why many Indigenous communities are disadvantaged in the socioeconomic conditions they experience

\footnotetext{
${ }^{2}$ The etymological meaning of 'democracy' is rule by the people.
} 
compared to non-Indigenous Australians (see, for example, Altman 2001b). For example, Indigenous people are more dispersed than other Australians, many live in remote regions with few employment opportunities, while poor education, housing, health and income status reinforces their disadvantage. Consequently, Indigenous Australians are significantly more likely to be impoverished than non-Indigenous Australians-across many indicators. ${ }^{3}$ Compared to non-Indigenous Australians, unemployment is 3.2 times higher for Indigenous peoples and Indigenous life expectancy is 17 years lower than that for the total Australian population (Steering Committee for the Review of Commonwealth Service Provision 2005).

Such circumstances illustrate that while Indigenous people are, in theory, able to access representative parliamentary structures on the same basis as non-Indigenous Australians, their standard of living or outcomes from education or health services are substantially below that of non-Indigenous Australians (Robinson and Sidoti 2000; Stokes 2002; Westbury 2003). Despite the complex of reasons for Indigenous disadvantage, imposed 'solutions' developed in distant centralised government clearly do not meet the needs of many Indigenous communities.

Furthermore, until relatively recently, Indigenous Australians enjoyed few formal legal and political rights, and struggled to access many mainstream government services. Limitations of parliamentary representation are starkly evident in the Indigenous experience: the small number of Indigenous voters and their geographic dispersal translates to little electoral 'muscle'. In a democratic system largely dominated by formal parliamentary representative politics, many Indigenous communities have been marginalised to the extent that they are unable to acquire political influence necessary to meet their objectives. In addition, disenchantment with formal structures and processes of representative parliamentary democracy has been deepened by concerted government efforts to facilitate mining, often regardless of the articulated opposition or concerns of local Indigenous communities (seen in the examples below). Such government actions over-ride the wishes of local communities, undermining the influence of Indigenous citizens in decisions that acutely affect them.

In addition, substitution - the risk of citizenship entitlements being deliberately reduced - is faced by some Indigenous communities where mining takes place. Government substituting royalty or other benefits derived from mining in the place of government provision results in a reduction of state finance for community services (Altman, Chapter 2; Levitus, Chapter 4; Altman and Pollack 1998; Banerjee 2001; O'Faircheallaigh 2004a; Rowse 2002). ${ }^{4}$ This is made more

\footnotetext{
${ }^{3}$ Scale of measurement used does not change this fact (Hunter 1999).

${ }^{4}$ For suggestions on how best to avoid this situation see O'Faircheallaigh 2004a.
} 
complex from a democratic perspective: perceptions that existing lack of government service delivery (or threatened reduction) might lead some Indigenous communities to acquiesce to mining if they view mining as the only means to obtain necessary outcomes - health and education services or employment, for example.

The deficiencies of representative democracy thus necessitate supplementary means of delivering democratic ideals such as self-determination and inclusion of those affected in policy-making (Hirst 1994; see also Dryzek 1996b, 2000a; Fliedner 2000; Goghill 2002; Rose 2002). Legitimacy and democracy should not be considered simply as a function of the tenure of elected officers, but should be judged according to how institutions (including non-state entities) address the expectations of those communities they impact. This broad understanding of democracy and governance is further warranted by apparent ability of certain groups to attain desired behaviour from powerful socioeconomic entities - including companies (see, for example, Dryzek 1996a; Eckersley 2000: 118; Maddox 1991; Moon 2003: 2-9; Pateman 1970; Suggett 2000).

If Indigenous communities can, using the tool of civil regulation (see Trebeck 2007a), compel companies to reflect their demands, then the sovereignty, self-determination and sustainability of these communities has been advanced. How this tool is manoeuvred to attain community expectations depends on several factors, pertaining to both the communities and the company in question. The examples below seek to elicit some of these factors to enhance understanding of the connection between corporate social responsibility and social sustainability.

\section{Corporate social responsibility: A definition}

This chapter conceives corporate social responsibility as those company activities, other than commercial outputs, and beyond legally required behaviour, taken in order to satisfy social needs and demands (see Trebeck 2008a). Motivation is of particular importance in this conception: these are activities taken in response to community demands or with a view to addressing social needs that impact the business. They are ultimately impelled by business needs, as opposed to moral or ethical connotations sometimes implied by 'responsibility'. The pragmatic rationale of such responsiveness reflects that in order to serve shareholder interests, attention to the demands of some groups beyond shareholders is necessary (see, for example, Moon 2003: 2-9; Power 2003; Spar 1998). According to a recent report, this might be understood as a business approach to social responsibility, seeking the company's own self interest to enhance long term value and risk reduction ${ }^{5}$ by addressing the social and

\footnotetext{
${ }^{5}$ Non-financial risks might include health and safety risks, protecting physical assets, compliance with regulations, product liability, brand reputation, asset vulnerability, changing markets, sabotage, human capital and so on (see Corporations and Markets Advisory Committee, 2006: 50).
} 
environmental operating context (a product of factors such as reputation, employee attraction, improving market position) (see Corporations and Markets Advisory Committee 2006: 34-68). Alternative approaches to a company's social responsibilities include a compliance approach, a philanthropic approach, and social primacy or social obligation approach. The compliance approach is based on obligation to comply with the letter of the law; at the same time, companies may benefit from complying with the spirit of the law as perceived by the general community. Under a philanthropic approach companies give to the community beyond their primary business. Under a social primacy approach directors pursue ethical goals beyond the spirit of the law, often in recognition that businesses have access to valuable resources and privileges, and therefore have a corresponding obligation to address social problems, even if there is not a clear benefit to the company (Corporations and Markets Advisory Committee 2006: 52-3).

\section{Civil regulation}

Bendell defines civil regulations as those 'pressures exerted by processes in civil society to persuade, or even compel, organisations to act differently in relation to social and environmental concerns' (Bendell 2000a; see also Murphy and Bendell 1999). ${ }^{6}$ A particular manifestation of civil regulation with salience for mining companies is the necessity to obtain and maintain a 'social licence to operate'. While minimum levels of acceptable company behaviour are specified in laws and regulations, social obligations are no longer discharged by simply carrying out legal minimum duties. Companies need to be not only 'morally and legally acceptable, but also popularly acceptable' (Fombrun 1997; Holme 1999; Lane 2001; see also Gunningham, Kagan and Thornton 2002; Piggot 2002; Warren 1999: 214-24; White 1999: 30-43). To attain this acceptability companies must be deemed to meet community expectations for certain behaviour, often beyond behaviour mandated by formal state regulations. In seeking a 'social licence to operate', corporate responsiveness to the demands of key communities brings companies to act, to some extent, according to the demands of certain communities (Moon 2003: 2-9).

Gunningham, Kagan and Thornton (2002) highlight that the terms of a company's social licence can be indirectly stipulated via mechanisms offered in the law and the economy: for example, through unofficial economic sanctions associated with negative publicity that reduces sales, investment in the company, and the company's access to capital (see also Kapelus 2002: 275-96). ${ }^{7}$ As seen in the case

\footnotetext{
${ }^{6}$ Corporate power has long been challenged by elements of society and social movements, such as the consumer movement in the 1960s, and the environmental movement of the 1970s. The history of business/civil society relations has been one of antagonism, until the early 1990s when partnerships for sustainable development began to emerge (see for further description Murphy and Bendell 1999).

7 Economic enforcement mechanisms invariably entail boycotts such as by consumers, investors or shareholders in their capacity as economic actors.
} 
studies below, local communities can also directly affect the commercial future of a company by threatening its ability to attain resources, such as employees, minerals, or access to operations using blockades, legal permissions or licences.

Community resistance can also be tacit, such as intransigence during land access negotiations. Or community resistance can be more palpable, such as public protest, physical occupation of a site, even sabotage. Direct action can in turn generate wider, indirect, implications. For example, causing a project to be delayed lowers the net present value of any future earnings steam. ${ }^{8}$ Moreover, local communities can use particular legislation strategically to exert leverage over companies. Similarly, formal regulations might be more rigorously enforced, or more stringent regulations introduced, as the result of community pressure.

Many companies are consequently recognising a 'pragmatic logic' in meeting community expectations given ability of local communities to impose costs on operations (Kapelus 2002: 275-96). Good corporate community relations, community engagement and efforts to meet community demands are the means by which companies can improve reputation and attain acceptance: their social licence to operate (Banerjee 2001; Cragg and Greenbaum 2002: 319-35; Parker 2002; Solomon 2000; Trebeck 2007a; Zadek 2003).

\section{Social sustainability through civil regulation and corporate social responsibility?}

In order to explore the bearing these processes have on social sustainability in the sense of community self-determination, several empirical examples are outlined here to assess whether the vulnerability of companies to civil regulation actually empowers those communities otherwise disempowered by formal representative democracy. These cases explore how corporate responsiveness to community pressures represents an opportunity for Indigenous people to express themselves beyond mainstream political structures, obtaining sought outcomes using extra-parliamentary tactics, such as a sit-in, shareholder activism, media campaigns or tactical use of legislation.

These case studies are only 'flashpoints' in complex ongoing relationships between respective mining companies and local Indigenous communities. They are not presented as definitive accounts, but as illustrations of the potential leverage affected communities might be able to exert over companies and of how impetus for responsiveness gain traction within respective companies. An understanding of why and when companies respond to community demands, appreciating the potential and limitations of community leverage, enables more nuanced analysis of opportunities for social sustainability.

\footnotetext{
8 Gunningham, Kagan and Thornton (2002) therefore find the concept of a multifaceted licence to operate that incorporates economic, regulatory and social pressures a more useful concept than a single aspect licence.
} 


\section{Century Mine}

In the Gulf of Carpentaria in Queensland many Indigenous people have low formal education and suffer poor health, with one of the lowest life expectancies on average in Australia. ${ }^{9}$ Until zinc mining began at Century Mine, most employment was through the Community Development Employment Projects (CDEP) scheme (Martin 1998b; Williams 1999). Gulf Indigenous communities have, however, to some degree been able to hold the operators of Century mine to account and attain certain concessions from the miner as a result.

In the 1990s local Indigenous communities, and in particular one charismatic individual accepted by many as representative of broader community views, were able to impel the prospective developer and operator of Century mine, CRA (Rio Tinto's predecessor in Australia), to the negotiating table. Early in negotiations for the mine's development the High Court of Australia, in what became known as the Mabo decision, ruled that Indigenous Australians had common law native title rights over unalienated land over which they could demonstrate continuous connection. Subsequent Commonwealth legislation - the Native Title Act 1993 - gave registered native title holders a 'right to negotiate', though not a right of veto, over mining (see Altman, Chapter 2; Rowse 2002). For a considerable period after 1993, the native title status over land containing the zinc deposit was unclear, hence CRA lacked a definitive legal license to develop Century, elevating the necessity of community agreement necessary for the mine's operation. Century's management also recognised that following instances of 'radical and aggressive community opposition' to Century's development, even if they secured legal permission to mine, without a social licence to operate the project would remain vulnerable to sabotage. ${ }^{10}$

The Queensland Government strongly supported the project, given Century's employment and regional economic importance. During a difficult point in negotiations, it even offered legislation to by-pass Commonwealth native title legislation, which would enable the mine to proceed, regardless of any claims Indigenous people might have under native title (Cook 1997). This option was refused by CRA which, as outlined below, had come to understand that such litigious tactics did not advance harmonious community relationships.

The emerging corporate strategy to seek community support came, however, from senior employees on the ground, rather than any directive from CRA headquarters. Recognition of Indigenous interests, and the potential implications of Indigenous opposition to mine development, was brought to Century by

\footnotetext{
${ }^{9}$ For example, Mornington Island and Doomadgee have very low environmental health infrastructure, and lack sufficient housing and water supplies (T. Koch, 'Murrandoo, the man', The Courier Mail, 23 November 2002, p.35; Martin 1998b ).

10 I. Williams, former Executive General Manager-Mining, Pasminco Ltd, pers. int., 4 August 2003.
} 
Century's Managing Director based on his prior experience with Hamersley Iron's Marandoo Mine in Western Australia (discussed below).

During a protracted negotiation period company negotiators increased an initial offer to local Indigenous communities of $\$ 70000$ cash to an eventual $\$ 60$ million package. The bargaining position utilised by Indigenous interests - by virtue of native title legal provisions, delay tactics and the use of public forums - rendered those seeking to 'regulate' the miner visible to company managers and prominent in company decision-making equations (Trebeck 2005; Trigger 1998). Delays impinging on commercial standing and threats to corporate reputation demonstrated that when Indigenous communities comprehend and penetrate contexts in which large companies operate, they can press for certain corporate behaviour and demonstrable community benefit.

In 1997 representatives from registered native title claimants, the Queensland Government, and Century Zinc Mine signed the Gulf Communities Agreement (GCA). The GCA enabled the mine to go ahead despite outstanding native title claims over the area. It committed the owner of Century to spend $\$ 60$ million (in 1997 terms) over the life of the mine on employment and training, community development, and payments to native title parties. It pledged native title groups to allow Century's operation in return.

Following the signing of the GCA, CRA (by then Rio Tinto) sold the mine to Pasminco, and Pasminco went into voluntary administration in September 2001 (eventually emerging in 2004 as Zinifex following significant balance sheet adjustments). With the financial problems that preceded administration, Pasminco's concern with community relations at Century lessened - the short term priority of financial sustainability ostensibly assumed priority, to the exclusion of other aspects of sustainability. Insufficient effort and resources were deployed to satisfy the expectations of local Indigenous communities, and Pasminco's focus was limited to compliance with strict contractual aspects of the GCA. Responsibility for GCA implementation was subordinated to a unit within Century's Human Resources. It seems that as Pasminco's financial concerns dominated, community relations suffered. Key individuals supporting community relations effort had left, been retrenched or were largely unable to achieve traction in a company where individuals with authority to affect substantial change no longer appreciated the relevance of the business case for sound community relations.

Nonetheless, prior to November 2002, Century believed it had developed 'good relationships with Indigenous people in the Gulf' (Hall and Driver 2002; Pasminco n.d.; Pasminco Century Mine 2001). In terms of Indigenous employment, Century has been the 'star performer' of the Australian mining industry: over 20 per cent of Century's workforce is Indigenous, the vast majority of whom are local (Pasminco Century Mine 2003). 
For many local Indigenous people though, the mine was not seen as delivering benefit to the region beyond employment of individuals (Hall and Driver 2002). ${ }^{11}$ There were a number of further complaints, but efforts to convey them to the company proved futile. In November 2002, between 50 and 80 people, mainly residents of Doomadgee (the Indigenous community closest to the mine), occupied the mine site kitchen. The protest did not halt production, but did constitute both an inconvenience and an underlying threat that the action could escalate and impede operations, a particularly ominous consequence given Pasminco's then perilous financial circumstances. After nine days an end to the sit-in was negotiated between those involved, Pasminco and the Queensland Government.

There seems to be recognition from both Indigenous people involved and Century that there has been positive change in the relationship between communities and company since the sit-in. ${ }^{12}$ One observer states that the sit-in gave the company a 'wake-up call' that it needed to pay more attention to community issues. ${ }^{13}$ It highlighted the repercussions of not being sufficiently proactive in community relationships. Since the sit-in '[Century's] eyes are back on the ball, they now appreciate that the GCA is their "licence to operate", and if they do not sufficiently implement the GCA according to community expectations they will lose this licence'. ${ }^{14}$

\section{Hamersley Iron}

In the late 1980s, Hamersley Iron ('Hamersley' now Pilbara Iron), a Rio Tinto subsidiary based in the Pilbara region of Western Australia, sought to develop the Marandoo iron ore deposit located within the Hamersley National Park, ${ }^{15}$ claiming that Marandoo was imperative to maintain supply of ore. ${ }^{16}$ Despite lacking the trust of many members of Indigenous communities in the Pilbara, Hamersley pursued development of the mine regardless. At this time, prior to the Mabo decision and the Native Title Act 1993, Hamersley used adversarial

\footnotetext{
11 D. Aplin, Doomadgee resident, member of GADC, pers. int., 10 July 2003; A. Chong, former Roche Eltin Joint Venture employee, Burketown resident, pers. int., 10 July 2003; D. Rose, General Manager Pasminco Century Mine, pers. int., 3 July 2003; C. Waldron, Doomadgee resident, pers. int., 10 July 2003.

12 D. Aplin, Doomadgee resident and member of GADC, pers. int., 10 July 2003; P. Cameron, Gulf region community liaison officer Pasminco Century Mine, pers. int., 13 July 2003; F. Pascoe, Indigenous Business Leader Aboriginal Development Benefits Trust Pty Ltd, Former GCA Manager, Normanton resident, pers. int., 11 July 2003; K. Quigley, Manager External Relations Pasminco Century Mine, pers. int., 1 July 2003; A. Waldron Doomadgee resident, pers. int., 10 July 2003.

13 C. Reading, Community Development Officer Pasminco Century Mine, pers. int., 2 July 2003; also J. Green, Carpentaria Land Council Doomadgee Office, pers. int., 10 July 2003; D. Rose, General Manager Pasminco Century Mine, pers. int., 3 July 2003; S. 'Bull' Yanner, GCA Superintendent Pasminco Century Mine, pers. int., 2 July 2003.

${ }^{14}$ F. Pascoe, Indigenous Business Leader Aboriginal Development Benefits Trust Pty Ltd, Former GCA Manager and Normanton resident, pers. int., 11 July 2003.

15 Now the Karijini National Park.

16 See B. Hextall, 'CRA clear to mine in national park', The Sydney Morning Herald, 16 November 1990; M. Stevens, 'Showdown at Marandoo', Business Review Weekly, 6 December 1991.
} 
and litigious tactics to progress Marandoo's development, including a media campaign to pressure the Western Australia Government to speed up approval processes. ${ }^{17}$ Marandoo was complicated by its location within a National Park and environmentalist's concerns about endangering a rare species of mouse. ${ }^{18}$ An alliance of sorts arose between environmental groups and Indigenous interests in opposition to the mine. ${ }^{19}$

Hamersley could not proceed with development until the project obtained clearance under Western Australia's Aboriginal Heritage Act 1972. Doing so required identification of Indigenous sites to prevent or minimise any site disturbance. Hamersley asserted that anthropological and archaeological studies conducted since 1974 found no significant Indigenous sites, and when taking ownership of the Marandoo area in the early 1980s it also acquired clearances obtained by the previous owners. ${ }^{20}$ Hamersley refused to conduct another survey of Indigenous sites at Marandoo. The Western Australian Government eventually commissioned a further study that found four sites of cultural significance, two of which were located on top of the ore body.

The demand for further surveys and compliance with the Aboriginal Heritage Act 1972 had significantly stalled Hamersley's intended development time frame. Rather than seeking to prevent the mine altogether, the main objective of many members of local Indigenous communities largely encompassed attaining recognition in negotiations about how Marandoo proceeded and benefits offered to those affected (G. Benn pers. comm. 2003). Delaying Marandoo was a strategy to pressure Hamersley to acknowledge Indigenous interests, enabling the communities to make demands such as increased Indigenous employment in Hamersley's operations. Heritage legislation was the best available (legal) 'device to achieve this' ${ }^{21}$

Despite resistance and concern in the local Indigenous communities about the destruction of sites, the Western Australian Government passed the Aboriginal

\footnotetext{
17 G. Benn, Aboriginal Legal Service, pers. comm., 5 August 2003; B. Larson, General Manager External Affairs Hamersley Iron, pers. int., 27 March 2003; J. van de Bund, former Manager Aboriginal Training and Liaison, Hamersley Iron, pers. int., 30 June 2003; J. Watson, Western Australian Minister for Aboriginal Affairs 1991-93, pers. int., 5 August 2003; I. Williams, former Group Project Leader Future Mine Resources, Hamersley Iron, pers. int., 4 August 2003.

18 H. Rumley, anthropologist, pers. int., 27 March 2003; M. Steketee, 'On the fast track to a dispute over Marandoo', The Sydney Morning Herald, 5 November 1991; I. Williams, former Group Project Leader Future Mine Resources, Hamersley Iron, pers. int., 4 August 2003.

19 T. 'Slim' Parker, at Tom Price, pers. int., 3 April 2003; G. Benn, Aboriginal Legal Service, pers. comm., 5 August 2003; J. Pettigrew, Western Australian branch of the Australian Conservation Foundation, quoted in M. Steketee, 'On the fast track to a dispute over Marandoo', The Sydney Morning Herald, 5 November 1991; C. Smith, Community Development Hamersley Iron, pers. int., 2 April 2003; J. Watson, Western Australian Minister for Aboriginal Affairs 1991-93, pers. int., 5 August 2003.

20 T. Darvall, 'Hamersley in Ad Offensive for Iron Project', The Age, 2 August 1991.

21 T. 'Slim' Parker, pers. int., 3 April 2003; J. Watson, Western Australian Minister for Aboriginal Affairs 1991-93, pers. int., 5 August 2003; I. Williams, former Group Project Leader Future Mine Resources, Hamersley Iron, pers. int., 4 August 2003.
} 
Heritage (Marandoo) Act 1992 that excluded the area from the Aboriginal Heritage Act 1972. The mine was constructed after a delay of two years and substantial legal cost to both the company and local communities (Bradshaw 1998; Eggleston 2002). Pertinently, Hamersley staff have since described the protracted processes of pursuing development as harrowing, expensive and significant enough to change the company's approach to community relations. ${ }^{22}$ Key company individuals realised such disputes are not good for long-term business activities and future mining activity in the Pilbara.

Instead, seeking to improve community relationships and prevent any future delay to its development plans, Hamersley established an Aboriginal Training and Liaison Unit in 1992 to increase Indigenous employment and repair company relationships with Indigenous people in the Pilbara. When it came to the Yandicoogina mine in 1997, in the post-native title climate, Hamersley undertook to negotiate and reach agreement with Indigenous representatives, rather than the legalistic and confrontational approach that characterised Hamersley's effort to develop Marandoo a few years earlier.

Hamersley now states that it recognises the existence of native title and the interest it bestows on Indigenous people as 'real stakeholders' in lands Hamersley uses for mining (van de Bund 1996). In recognising certain demands and expectations of local Indigenous communities, Hamersley aims 'to meet its strategic goals of maintaining access to land and resources and having the necessary flexibility in [its] operating environment' (Hamersley Iron 2000). It has been Indigenous leverage, potently demonstrated in the delay of Marandoo, which drove this strategy of responsiveness, reinforced by changes to community relations strategies adopted by Hamersley's parent company, Rio Tinto.

\section{Rio Tinto's Indigenous relations}

Changes in Hamersley's approach to external stakeholders were given added momentum by support from senior managers within Hamersley's parent company, Rio Tinto. Key managers discerned the potential benefits from improved Indigenous relations, and were able to shift company policy towards one more responsive to the expectations of relevant Indigenous entities. Rio Tinto's transformation from campaigning to minimise recognition of Indigenous rights (see for example Howitt 1998), to seeking a reputation as Indigenous Australia's preferred development partner, has been self-described as a 'philosophical sea-change' (Cusack 2001). The Marandoo dispute highlighted the prudence of this new strategy, augmented by the advent of native title. Agreements with Indigenous interests being a matter of course in Rio Tinto

22 D. Trigger, Anthropology Department, University of Western Australia, pers. int., 25 March 2003; B. Larson, General Manager External Affairs Hamersley Iron, pers. int., 27 March 2003; J. van de Bund, former Manager Aboriginal Training and Liaison, Hamersley Iron, pers. int., 30 June 2003; see also Rio Tinto Limited 2001. 
operations overseas, rising risks to reputation through non-governmental organisation scrutiny, and violent physical protest and subsequent premature closure of Rio Tinto's (then CRA) Bougainville Copper Mine in Papua New Guinea cumulatively demonstrated the prudence of increased community relations effort (see Trebeck 2005). As Rio Tinto's Chief Financial Officer explained, 'the business case [for corporate social responsibility] rests first on risk mitigation. Without corporate social responsibility, a mining company may eventually be unwelcome as an investor in its host environment ${ }^{\prime}{ }^{23}$

Individual employees appreciated the imperative for change and drove its initiation. For example, the leadership of Rio Tinto's then Chief Executive Officer, Leon Davis, is considered crucial in initiating change and enabling implementation of new community relations policies. Davis has been described as 'spearheading' the company's decision to shift from legal wrangling to negotiations with Indigenous people. ${ }^{24}$ His seniority in the company hierarchy presented an ability to effect change quickly, underpinned by an appreciation of the business case and personal commitment to harmonious relations with Indigenous Australians.

In particular, Davis has been described as 'that way inclined anyway' towards supporting positive outcomes for Indigenous people. ${ }^{25}$ His efforts in Indigenous relations were in part premised on his long-held beliefs that companies can deliver social benefit, and that Indigenous Australians deserved better treatment from mining companies. His career included work at sites overseas where engagement and deals with local people were routine, and also at Bougainville in Papua New Guinea where hostility of local people forced early mine closure in 1989. Davis describes

the loss of the [Bougainville] mine as a huge shock. It was an awful thing to happen. BCL was a huge investment, and the diamond in the CRA crown. Bougainville was a lesson I learnt and which I took with me. ${ }^{26}$

Following advocacy of the prudence of corporate social responsibility by Davis and others with similar perceptions, Rio Tinto's new position regarding Indigenous relations was publicly stated in 1995. In a landmark speech, Davis articulated 'satisfaction' with the main tenets of native title legislation, and outlined Rio Tinto's changed approach towards Indigenous communities near its operations: away from a litigious stance towards development of mechanisms to share with and compensate Indigenous people for mining activity on their land (Davis 1995). Davis describes this move as 'hard headed'. ${ }^{27}$

\footnotetext{
${ }^{23}$ G. Elliot, Chief Financial Officer, Rio Tinto, quoted in World Economic Forum 2004.

24 P. Manning, 'Poor fellow mining country', Sydney Morning Herald, 18 April 2003.

25 I. Williams, former Executive General Manager-Mining, Pasminco Ltd, pers. int., 4 August 2003.

26 L. Davis, pers. int., 14 February 2005.

27 L. Davis, pers. int., 14 February 2005; Davis 2002.
} 
Rio Tinto business units were told by the company's Head Office that they needed to alter their Indigenous relations approach and practice. New strategies were mandatory, but should be structured according to local circumstances. Middle managers, facing pressures of output quotas, make decisions according to company policy and incentive structures, underlining the importance of high-level directives in realising internal change. Company policies and mandates bridge any perceived short-term costs (immediate outlays for developing community relations), with the long-term corporate gains (enhanced company reputation and improved land access). Public declaration of the need to achieve positive relationships with Indigenous people also aided Rio Tinto employees already predisposed to more conciliatory external relations.

The story, of course, is not one of universal acceptance and smooth implementation. The external face of Rio Tinto's corporate social responsibility in the form of publicised programs and publications masked internal dissent and scepticism. For example, when Rio Tinto's Indigenous employment program was introduced at company mine sites, there was little enthusiasm for the new strategy and the effort it required (Mays 2003). Despite high-level decrees from those charged with management of Rio Tinto's external operating context, many mid-level employees retained the perception that technical competence is the main ingredient for corporate and personal success. Perception of the long-term corporate interests (which often justifies community engagement) seems fundamental to appreciating success factors as existing beyond short-term budgetary objectives.

\section{Jabiluka}

Rio Tinto's changing approach towards responsiveness to those with capacity to impact mine operations constitutes the background in which Rio Tinto acquired North Limited in 2000. North owned 68.4 per cent of Energy Resources of Australia (ERA), which owned the Jabiluka uranium mineral lease in the Northern Territory. The Jabiluka example illustrates the sorts of circumstances that might prevent mining altogether. In seeking to attain a social licence to operate, the language of 'win-win' outcomes is often used by miners to justify their presence and promote what they bring to a community. This assumes that mining will proceed and that local communities can derive outcomes sufficiently beneficial they can be described as a 'win' for the communities. Such language and its implication leaves little room for communities to reject mining outright. The campaign against development of Jabiluka illustrates how such a rejection can be enforced - that is, how the social licence to operate can be withheld (see also Trebeck 2007a, 2009).

The anti-Jabiluka campaign involved the confluence of three issues: local Indigenous opposition, Jabiluka's location surrounded by the World Heritage listed Kakadu National Park, and concerns over uranium mining. Protest by 
campaigners for Indigenous land rights, environmentalists, and anti-nuclear activists encompassed legal action, efforts at education, mobilisation of national and international opposition, physical demonstrations, shareholder activism and parliamentary lobbying. The culmination of these components of the campaign against Jabiluka meant that a seemingly hopeless situation faced by a small and historically marginalised community was transcended. Jabiluka became an iconic struggle for anti-uranium stalwarts, but anti-uranium and environmental opposition to Jabiluka derived much potency from the discontent of traditional owners - the Mirrar people. Key traditional owners of the Jabiluka prospect have been unambiguous in their opposition to Jabiluka's development in recent times, opposition informed by concerns over the disturbance of sacred sites and experience of the nearby Ranger uranium mine where social and environmental impacts are considered adverse.

Campaigning by the Senior Traditional Owner, Yvonne Margarula, and the then Executive Officer of the Gundjehmi Aboriginal Corporation, Jacqui Katona, mobilised the international non-governmental organisation community, and led institutions such as the European Parliament and the United States Congress to pass resolutions against Jabiluka's development. In 1998 Margarula attended the United Nations Educational, Scientific and Cultural Organisation (UNESCO) World Heritage Bureau meeting in Paris, instigating a UNESCO Mission to Kakadu. The mission reported to the United Nations World Heritage Committee that there were 'significant ascertained and potential threats' to the National Park associated with development of Jabiluka, and recommended construction work at Jabiluka be halted.

The Australian Government refused to adopt these recommendations and the Department of Foreign Affairs reportedly spent six months and over \$1 million lobbying the United Nations World Heritage Committee and key decision-makers in its member countries, ultimately leading to the United Nations not placing Kakadu National Park on the endangered list (Banerjee 2000).

Jabiluka was opposed by many of Australia's environmental organisations, church, trade union and community groups. The Australian Senate passed a resolution opposing Jabiluka's development. An opinion poll in 1998 found that 67 per cent of Australians were against mining at Jabiluka. ${ }^{28}$ In urban centres protest against Jabiluka grew, including large rallies and public events in all capital and many regional cities. In March 1998 a blockade was established near the Jabiluka site, lasting eight months and involving over 5000 people. More than 500 protestors were arrested for trespass, including traditional owner Yvonne Margarula. The blockade meant that the company could not access the mine site as desired, despite being given legislative permission to mine and

\footnotetext{
${ }^{28}$ Quoted in C. Miller, 'North shareholders protest over Jabiluka', The Age, 4 June 1999, p. 7.
} 
supported by strong government backing. By flying employees and equipment to the site by helicopter ERA was, however, able to complete construction of the mine decline and retention pond in 1999.

ERA and its parent company North thus faced prolonged opposition to development of the Jabiluka mine. Annual General Meetings and company headquarters became 'combat zones' where anti-Jabiluka campaigners targeted shareholders and company management. ${ }^{29}$ In March 1999, the Melbourne premises of North were blockaded for four days. Activists also lobbied major North investors directly. Various financial institutions were sent anti-Jabiluka material, and in 1998 there was a national day of action targeting North's main bank, Westpac, for its involvement. By June 1999 almost \$7 million worth of North shares had been divested. Insurance company NRMA, for example, stated publicly that the reason for selling its North shares was concern about Jabiluka, deeming the project to be financially, politically and environmentally risky. ${ }^{30}$

Alongside the disinvestment by some financial institutions, there was strident shareholder activism. The Wilderness Society obtained North's share register and contacted over 67000 shareholders, informing them about Jabiluka and instigating the formation of a shareholder pressure group, North Ethical Shareholders. In October 1999 an Extraordinary General Meeting was held at the instigation of North Ethical Shareholders. Although the proposals put by the North Ethical Shareholders were defeated, the event attracted significant negative publicity for North and required diversion of management time to dealing with the activists. ${ }^{31}$

It seems, given North's strident pursuit of Jabiluka's development and its reaction to protests, that the company was almost impervious to many elements of the anti-Jabiluka campaign. Construction at the Jabiluka mine took place regardless of traditional owner objections. Arguably, if elements of the campaign such as urban protest and international institutions opposing the mine did not achieve their objective, they at least bolstered traditional owners in their manoeuvring against Jabiluka.

A significant lever that traditional owners wielded was the location of the mill for Jabiluka ore and an access road between nearby Ranger and Jabiluka. Traditional owners, by virtue of a clause in a 1991 lease transfer agreement (transferring ownership from Pancontinental to ERA), held an effective veto over milling of Jabiluka ore at the Ranger mill. The cost of building a mill to process Jabiluka ore at the Jabiluka site was over $\$ 200$ million, a cost ERA hoped to avoid by trucking ore to the existing Ranger mill 22 kilometres away. In the

\footnotetext{
29 J. Rose, pers. int., 29 March 2004; D. Sweeney, anti-nuclear campaigner, Australian Conservation Foundation, pers. int., 1 April 2004.

30 Cited in The Wilderness Society and The Mineral Policy Institute 1998.

31 J. Rose, 'Blame it on the Rio Tinto moment', The Australian Financial Review, 12-16 April 2001, p.10.
} 
context of then poor uranium prices, the veto over doing so, effectively necessitating construction of a new mill at Jabiluka, made the economics of the Jabiluka project far less attractive to ERA and North.

There were two phases in the campaign to stop development of Jabiluka-before and after 2000 when Rio Tinto acquired North, and with it majority ownership of ERA. Rio Tinto would seek to avoid mining without community consent, whereas North seemed to rely on government sanction to mine, regardless of whether local communities sanctioned this or not. Rio Tinto's position was that although the Northern Territory and Commonwealth Governments supported the mine, this was insufficient, as consent was also needed from traditional owners. Paradoxically perhaps, being a large international company with an important brand, making a concerted public effort to move away from historic poor performance, and seeking to cultivate positive reputation amongst Indigenous communities more broadly, Rio Tinto was seemingly unwilling to weather the reputational attacks that North ostensibly tolerated. The potential cost to Rio Tinto's reputation of proceeding with Jabiluka in the face of local opposition was increasingly evident as adverse market conditions for uranium in the few years after acquiring ERA made Jabiluka relatively marginal to Rio Tinto's overall commercial strategy - as one observer said, the Rio Tinto brand was 'suffering much grief for a little mine'. ${ }^{32}$ For example, in September 2002 Rio Tinto's stake in ERA was worth $\$ 172$ million, less than 1 per cent of Rio Tinto's total net present value. ${ }^{33}$

In late March 2001, Rio Tinto's Chief Executive Officer indicated that the company would not support development of Jabiluka unless there was a substantial alteration of community attitudes, alongside improved uranium prices (Clifford 2001). ${ }^{34}$ This moderate concession did not placate the anti-Jabiluka campaign. At Rio Tinto's Australian Annual General Meeting the following month protestors held a 'die-in' and company shareholders were forced to step over 'dying' protestors. ${ }^{35}$ At Rio Tinto's London Annual General Meeting the next year, a statement on behalf of traditional owners was presented, rejecting mining on Mirrar land and demanding that Rio Tinto leave the area. In September 2002 Rio Tinto Chairman Sir Robert Wilson strengthened his company's position not to mine Jabiluka without acceptance from traditional owners; he also stated, for the first time, that the site would be rehabilitated and the mine's entrance

\footnotetext{
32 D. Sweeney, anti-nuclear campaigner, Australian Conservation Foundation, pers. int., 1 April 2004.

33 B. Hextall, 'Rio keeps door open', The Australian Financial Review, 6 September 2002, p. 65.

34 Wilson, for example, highlighted the lack of viability of Jabiluka mine as an important consideration - admitting 'we don't see the development as being viable in any case' (quoted in I. Howarth, 'Rio Tinto concedes defeat on Jabiluka', The Australian Financial Review 4 April 2002, p. 59; and J. Rose, 'Blame it on the Rio Tinto moment', The Australian Financial Review, 12-16 April 2001, p.10).

35 Organisations included Friends of the Earth, the Mineral Policy Institute, Greenpeace, and the Australian Conservation Foundation.
} 
sealed. ${ }^{36}$ Until this declaration, the Mirrar had understood that despite their protests the Jabiluka mine could still go ahead without their approval once Ranger was no longer operational. An agreement (the Jabiluka Long Term Care and Maintenance Agreement) has subsequently been developed between ERA and traditional owners and their representatives, regarding rehabilitation and maintenance of the Jabiluka site and future consultation over development.

An important element of the Jabiluka campaign, with parallels in both Hamersley Iron's experience at Marandoo and negotiations for Century mine, was the role of government. In each case both state and Commonwealth governments sought to facilitate mine development, including passing special legislation or ignoring United Nations recommendations. Government approved development of Jabiluka in spite of protests by traditional owners, as well as wider opposition. Government support for Jabiluka has been on 'national interest' grounds, with the Prime Minister citing the imperatives of globalisation as necessitating Jabiluka's development. ${ }^{37}$

Some commentators have portrayed Rio Tinto and ERA's position of not mining without local community consent, and the anti-Jabiluka campaign that drove this strategy, as a 'David and Goliath' win for the Mirrar people. Katona observes that it demonstrates how:

a bunch of women from the bush, the majority of whom were illiterate, spoke English as a second or third language, stuck to their guns, and took on the mining company, and hunted them down ... Wherever the mining company was speaking publicly we were able to have agents or representations made ... directly to the face of the company to ... let them know that we were not going to be beaten.... ${ }^{38}$

It shows what leverage is necessary to capture corporate attention and response: ability to impact the commercial position of the company, whether in the short term through economic levers or over the long term via influence on company reputation.

\section{Discussion and conclusion}

These case studies suggest that uptake of corporate social responsibility depends on responsive individuals in the company, especially senior management, being receptive to the pressures for responsiveness; namely those that appeal to commercial interest. Once a company has accorded a community group or organisation 'stakeholder' status, the degree to which their demands are acknowledged and addressed is a function of how managers perceive stakeholder

\footnotetext{
36 'Jabiluka in Mirrar hands', The Northern Star, 6 September 2002, p. 23.

37 Prime Minister Howard cited in G. Milne, 'Howard's in the red over Brown and Greens', The Australian, 7 December 1998, p. 15.

38 ABC Radio National, Late Night Live, 21 August 2003.
} 
power (to impact on the firm), the legitimacy (of the group or its claim) and urgency with which the demands are pressed (Agle, Mitchell and Sonnenfeld 1999; Mitchell, Agle and Wood 1997). While urgency seems difficult to delineate from power (beyond how acutely demands for response impact on shareholder value), responses seen in the case studies suggests that power is the most relevant element in this equation. It was those communities able to affect the company's capacity to operate which were accorded most corporate attention. The immediate response to the sit-in at Century mine, after little response from the company to written attempts at communicating aspirations, starkly demonstrates this, as do the various elements of the anti-Jabiluka campaign.

Moreover, comparison of North and Rio Tinto's handling of the anti-Jabiluka campaign, and in particular reaction to traditional owner opposition, illustrates divergent criteria for stakeholder legitimacy: North adopted Western-centric 'majoritarian' notions of who speaks for land (Trebeck 2005), while Rio Tinto accorded value to authority based on traditional ownership according to Indigenous political systems and sought to respond to the concerns of these community groups in particular.

The case studies also demonstrated how interpretation of community demands for corporate social responsibility is often shaped by the values held by a corporate executive, or their experience of a crisis where the company's social licence to operate was jeopardised (Agle, Mitchell and Sonnenfeld 1999; Parker 2002; Webley 2001). Orlitzky and Swanson (2002) model this as how 'attuned' executives are to the demands of relevant stakeholders. For example, when a crisis (such as delay of Marandoo or closure of Bougainville mine) demonstrates capacity of certain stakeholders to impede company operation, individuals within the company who are pre-disposed to corporate social responsibility, even for 'moral' reasons, gain leverage for their views, while recalcitrants might come to appreciate the business case for it. Personal commitment to corporate social responsibility for moral reasons thus co-exists alongside the business case that drives prudent support for corporate social responsibility.

While a moral motivation might be sufficient in some cases and for some individuals, because the raison d'être of companies is profit and commercial continuity there is a need to understand and communicate the business case for corporate social responsibility internally to achieve change in corporate responsiveness to community demands. Only when the strength of a business case is evident will resources be dedicated to implementing corporate social responsibility (McLaren 2002; Parker 2002). Thus, if an individual or group is completely ineffectual in relation to a company, then there is unlikely to be a persuasive business case for the company to respond to the interests of these entities, save for a sense of moral duty held by some individuals within a firm. 
The examples of Century, Hamersley Iron, Rio Tinto and the anti-Jabiluka campaign support the contention that key individuals within organisations, notwithstanding any personal moral motivations, ultimately rely on business case arguments to gain internal traction for change and operational support for corporate social responsibility initiatives. In turn, however, the effectiveness of otherwise austere structures and policies comes from individuals. These individuals may be driven by either an appreciation of the business case, company policies, promotion and pay incentives, or moral commitment to improved Indigenous relations (Trebeck 2005).

That civil regulation often hinges on key individuals can, potentially, constitute risk. When such (arguably 'enlightened') individuals leave or when incidents that initially highlighted the need for corporate social responsibility recede in relative prominence in management attention then the drive and vigour of implementation is likely to abate. For example, for a time corporate social responsibility was ostensibly deemed relatively less important than the eventual catastrophic financial situation of Century's parent company. Developing structures to internalise corporate social responsibility might reduce the burden of advocacy away from a few individuals. Equally, however, structures themselves are insufficient: frameworks and programs to deliver corporate social responsibility are of little use if those charged with implementation do not do so with enthusiasm, understanding and appreciation of the necessity of their task. This was evident in the way some committees created to implement the GCA at Century were mismanaged, becoming counter-productive and a cause of community discontent that eventually impelled, in part, the 2002 sit-in (Trebeck 2005).

Civil regulation then is successful when community actions (or deliberate inactions) recognise that the most effective way in which to shape company behaviour is via financial gain or loss, thereby creating a business case for desired corporate change. It is individuals in the company who must recognise this business case, as occurred when management attention to the need for sound community relations became focused by incidents such as Bougainville's forced closure, the Marandoo dispute, the advent of native title, Century's sit-in and the anti-Jabiluka campaign. Here, a shift in the balance of external influences brings Indigenous demands to the fore by - directly or indirectly - threatening financial performance. When such civil regulation consequently gains corporate response there has invariably been a convergence of personal commitment and commercial imperative.

Given that companies are neither uncomplicated nor internally homogeneous, community pressures for corporate social responsibility will affect respective elements of a company differently. Adding to this complexity, both the organisation itself and individuals within it, function within a diverse social 
system (Keskinen, Aaltonen and Mitleton-Kelly 2003). Companies are porous entities, with individual employees having their own external networks that inform their actions and motivations. Once the objectives of individuals within companies are accumulated, and external stakeholders accounted for, companies can be seen as assemblies of relationships with respective audiences, requiring specific corporate responses and actions. This was evident, for example, in the divergent expectations of corporate behaviour held by the financial sector, compared with those of local communities, seen during Pasminco's financial difficulties.

There are frequently structural causes of such divergence. Employees at mine sites - where much corporate social responsibility is made manifest - often have strict job requirements that encompass output quotas, directing their priorities towards immediate production targets. Business units are faced with contradictory signals from headquarters, with consequent dilemmas regarding priorities: they must deliver production targets, reduction of costs and manage industrial relations, while also being expected to implement more intangible, costly community relations initiatives with their inherently longer-term outcomes. Time and production constraints in pursuit of profit often override other pressures. If corporate social responsibility initiatives are deemed expensive relative to other objectives, they are unlikely to be entered into, unless mandated by headquarters. Those at headquarters are charged with navigating the company's external environment for the longevity of shareholder value, whereas managers at mine sites appreciate less the geographical cross-subsidisation of reputational capital.

In addition, an essential element in the notion of civil regulation is the section of civil society doing the 'regulating'. Findings from the case studies suggest that there are several characteristics of civil society that might undermine the capacity of civil regulation to deliver beyond isolated instances. The representativeness of civil society - how those organisations demanding change from companies reflect the actual needs and demands of those in whose interests they purport to act-is vital. The greater the deficit in organisations' representativeness, the greater the likelihood that results of civil regulation will be skewed away from the interests of those affected. Such distortion, where outcomes do not reflect the actual wishes and expectations of communities, undermines any advancement of citizen sovereignty over companies.

The nature of the 'civil regulators' is an area for further research. It is worth suggesting, however, that it is in the company's interest to understand how any organisation actually relates to and represents its constituents - relationships will ultimately be undermined if citizens feel they are disenfranchised by engagement taking place between companies and certain elements of civil society. The structure of Century's GCA reflects dilemmas associated with civil society 
organisations. Part of the discontent that led to the 2002 sit-in at Century Mine was a feeling amongst some local Indigenous community members that they had not been sufficiently accounted for in the GCA, referring to themselves as 'the forgotten Waanyi' and eventually seeking alternative means (the sit-in) by which to achieve their demands.

Given these (and other) caveats, civil regulation and increased community participation in corporate decision-making is insufficient to attain the stated aims of particular communities (Bendell 2000a; Trebeck 2005; see also Maddox 1991). This limits the scope for social sustainability potentially realised through corporate social responsibility. Moreover, necessity of the business case highlights a role for civil society in maintaining vigilance and sustaining the context that prompts companies to consider communities. Inevitably the capacity of civil society to sustain this vigilance will be shaped by factors underpinning a community's sustainability, while corporate social responsibility itself can increase the sustainability of a community (see Trebeck 2007b). Emerging from this complex multi-directional relationship is evidence that the success of civil regulation to deliver community wishes in some contexts, as illustrated above, does illustrate that social sustainability can be advanced by utilising various levers to alter corporate operating frameworks. 